\title{
THE INTERNATIONAL WILDFLOWER FESTIVAL AND THE IMPLEMENTATION OF SUSTAINABLE MOBILITY AS TOURISTIC PRACTICE
}

\author{
TATIANA BAJUK SENČAR
}

This ethnographic discussion centers on the multi-faceted relationship between heritage and tourism in Bohinj, examining the ways in which heritage operates as a site for deliberating the challenges of developing and maintaining a sustainable form of tourism within Triglav National Park. Keywords: heritage, tourism, (sustainable) mobility, tourist landscapes, festivals, cultural landscapes, heritagization, wildflowers
Avtorica članka obravnava večplastno razmerje med dedišcino in turizmom $v$ Bohinju ter analizira, kako dedišcina deluje kot stičišce za obravnavo izzivov razvoja vzdržne oblike turizma $v$ Triglavskem narodnem parku. Ključne besede: dedišcina, turizem, (trajnostna) mobilnost, turistične krajine, festivali, kulturne krajine, dedišcenjenje, alpsko cvetje

This ethnographic discussion ${ }^{1}$ centers on the multi-faceted relationship between heritage and tourism in Bohinj, examining the ways in which heritage operates as a site for deliberating the challenges of developing and maintaining a sustainable form of tourism within Triglav National Park. In particular, I will frame this study in terms of tourist mobilities and in so doing analyze the links between tourist mobilities, tourism practices and the productions of Bohinj as a tourist destination. In this context, I am not only referring to mobility in the abstract sense, although it goes without saying that mobility understood as the movement or circulation of guests is the fundamental mainstay of tourism as a social practice and industry. Instead, mobility here refers primarily to travel as a grounded practice, focusing on the traffic of social actors, the routes as well as the forms of transport they employ, and the traces that their travel leaves behind on the physical and social landscape (Ingold 2004). In particular, I will use as a common thread the mutually constitutive relationship between tourist mobilities and the production of tourist landscapes in order to trace out the social context that informed the relatively recent creation of Bohinj's International Wild Flower Festival. This yearly festival held for two weeks in late spring comprises a range of diverse events designed to celebrate, promote, and raise awareness of wildflowers as an intrinsic element of Bohinj's natural and cultural heritage and their place in everyday life.

This analytical framing hinges on the premise that the heritagization of Bohinj refers to a set of evolving social practices, exemplifying the very nature of heritage that is defined

1 This article is based on research conducted within the scope of the following research projects: the completed project Triglav National Park: Heritage, Actors - Strategies, Questions and Solutions led by dr. Jurij Fikfak (J6-4310) and the ongoing project DriveGreen: Development of an Ecodriving Application for a Transition to a Low-carbon Society (L7-6858) led by dr. Dan Podjed. Both of these research projects are funded by the Slovenian Research Agency. 
by Barbara Kirshenblatt-Gimblett as an ongoing metacultural process (2004). In addition, this study centers on understanding the mutually constitutive connections between tourist mobilities and residents' definition of their relationship to different aspects of the landscape in which they live. This includes those landscape elements accorded the status of heritage (Bendix 2009); in the case of the wildflowers, this relationship can also be defined with the creation of a festival. ${ }^{2}$

In this study, I will not be addressing the nature of festivals per se, which has been the focus of detailed research across numerous disciplines. Anthropological studies of ritual have focused on a number of issues, including festival's structure as cultural ritual (Turner 1969; 1982) and festival's role (or lack thereof) in diverse societies (including Boissevain 1992; Durkheim 1964, Geertz 1973; Manning 1983). The role of tourism in the production and performance of festivals has been the subject of extended anthropological research, due also to rise of the festivals and their ever stronger role as tourist events. The central issues that have guided research in this vein include the commodification of festivals within the context of tourism (including Boissevain 1996a; Crain 1992; Greenwood 1989) and the consequent effects that such processes have on the cultural meaning of festivals and their authenticity (Boissevain 1996b; Cohen 1988; Selwyn 1996; Taylor 2001).

Moving beyond the issue of authenticity that has was long been an essential component of tourism research (MacCannell 1976), studies concerning festivals and tourism address the role that festivals play in the production of locality and "place-myths" upon which the tourism industry is based (Lash and Urry 1994). Numerous analysts across disciplines have called attention to the potential role of festivals in defining and promoting locality and the local identity of tourist destinations (including Getz 1991, 2004; Hall 1992; Kozorog 2009, 2011; Prentice and Andersen 2003). The aim of this ethnographic discussion is to build upon existing research through the introduction of mobility as an analytical frame for the study of heritage, festivals, and local identity.

Given that tourism is by nature a phenomenon that hinges on the movement of persons across borders (Lett 1989), movement and travel are intrinsic components of tourism that have been the subject of considerable research. Researchers have focused on tourists' travel in order to understand the nature of tourism as a social process (for example, Bruner 2005, Clifford 1997, Weber 2003) and the impact of tourist mobilities on tourist destinations (including Sheller and Urry 2004). Studies focused on social actors' mobile practices regarding particular forms of transport provide a foundation for the following analysis focused on grounded patterns of mobile practices. This study is informed primarily by research on automobile driving (Böhm et 2006; Dant 2004; Edensor 2004; Featherstone 2004; Miller 2004) and the sorts of places that driving practices create (Merriman 2004).

2 Elements of Bohinj's culture and tradition have in an analogous manner been heritagized in the creation of certain holidays, which have also assumed the status of tourist events. See Habinc 2013 for an analysis of select Bohinj holidays. 
This analysis is based on identifying and analyzing depictions of Bohinj as a tourist destination with the aid of images and discourse. These images circulate publicly in a number of ways. They can be launched with the aid of tourism promotional material, they can be lauded or criticized in the public media, they can be presented as targets in tourism strategies, and they can be the subject of everyday talk among those who live, work or visit Bohinj. This study is focused on analyzing these images identified or disseminated through various media or evoked in interviews conducted with Bohinj residents and tourism actors. A discussion of the images is framed against the backdrop of the issue of mobility and the challenges that it presents to tourism development. A presentation and analysis of the discourse and images of Bohinj's wildflowers upon which the festival is based builds upon this discussion. However, this analysis begins with a short overview of the key phases of Bohinj's development as a tourist destination through the lens of mobility.

\section{BOHINJ AS A NATURAL OASIS}

Bohinj is often depicted as a place of relatively untouched nature, which highlights its distinctiveness vis-a-vis Bled. Both tourist destinations center around lakes, yet the difference between Bohinj and Bled is often expressed in terms of Bled as a beautiful alpine resort and Bohinj as a natural oasis. ${ }^{3}$ The depiction of Bohinj as a natural oasis is also echoed in the discourse of Bohinj's tourism strategy as a central concept of its vision for Bohinj ${ }^{4}$ and present in other forms of promotional material, including websites of tourist accommodations such as Apartmaji Hriberski, located in Bohinjska Bistrica:

If you are looking for big hotels, cheap cafeterias, and smoke-filled taverns, then do not come to Bohinj, because this is not the place for you. Bohinj is namely a pleasant place and oasis of surprises. This place is suitable for all inquisitive visitors, those who seek new experiences, for researchers, adventurers, and dreamy souls. Above all, this is the place for those people who behave respectfully towards others as well as towards nature and cultural heritage. ${ }^{5}$

3 For example, see the discourse on Bled's official tourism website where Bled is depicted as "one of the finest Alpine resorts". See the following website: http://www.bled.si/en/about-bled. On the other hand, Bohinj's tourism website describes Bohinj as an "oasis on the sunny side of the Alps" (http:// www.bohinj.si/en/about_bohinj/learn_about_bohinj/natural_attractions).

4 The official tourism strategy document is published in the following document: Strategija razvoja in trženja destinacije Bohinj 2012-2016 / Strategy of development and marketing of the destination of Bohinj 2012 - 2016 (Lešnik Štuhec et al. 2012).

5 This is an excerpt from the text found on the website promoting Apartmaji Hriberski (http://www. apartmaji-hriberski.com). All translations from Slovene are mine. 
The portrayal of Bohinj as a natural oasis in the Alps, a natural refuge away from the everyday world is reflected to some degree in its accessibility. While for automobile drivers Bled is located just a few kilometers away from one of Slovenia's major highways, Bohinj is relatively less accessible: the most frequented route is the one that requires going through Bled and then through the winding Soteska valley. Bohinj is of course also accessible by train and other forms of public transport (most notably regional bus lines), and the railway played an important role in the development of tourism in Bohinj. There are also other, less frequented routes to Bohinj by car - either over the Pokljuka plateau or from the Primorska region, from the village of Podbrdo and crossing Soriško ridge — both of which require driving along windy mountain roads to reach Bohinj's valleys. The shape of tourism mobility today, which is based primarily on individual motor vehicles, contributes to the framing of Bohinj a less accessible place.

\section{BOHINJ AS A TOURIST DESTINATION THROUGH THE LENS OF ACCESSIBILITY}

The standards and criteria that define the accessibility of spaces and places shifts over time, and the criteria for defining Bohinj's accessibility have changed significantly over the centuries. For example, Ivo Cundričs history of Bohinj through the lens of iron ore mining demonstrates the formative role that iron ore mining played in Bohinj's development (Cundrič 2002). During Roman times, Bohinj was quite well-known within the province of Norik in which is was located and had strong social and economic ties. This was due in great part to iron and iron-ore mining, around which life in Bohinj centered for virtually a thousand years. The quality of iron ore in Bohinj was well-known in the Roman times, and its quality lauded even by the Roman poet Ovid who wrote that the strongest iron was forged in Norik fires (Cundrič 2002: 14). Iron thus literally put Bohinj on the map, and its location on a well-traveled route between Aquilea and what is now Klagenfurt helped Bohinj to flourish during this period. Its location and accessibility (defined in accordance with the valid criteria of the time) allowed iron ore mining to play a central role in defining Bohinj's place in the ever-evolving economic and social landscapes of the region. Iron ore remained an important factor shaping everyday life in Bohinj to varying degrees until the end of the 19th century.

The burning down of the iron ore mine in Bohinjska Bistrica in 1890 marked the end of the iron ore era and the beginning of a period of crisis, and it took many years for Bohinj to recover from all the changes that the loss of the mine implied. However, this crisis was resolved with another important event, one that reconfigured Bohinj's accessibility: the construction of the railway from Jesenice to Gorica that came through Bohinj and, more importantly, the railway tunnel that connected Bohinj with the Primorska region, which was finished in 1906. Incorporating Bohinj into the existing railway system implied connecting 


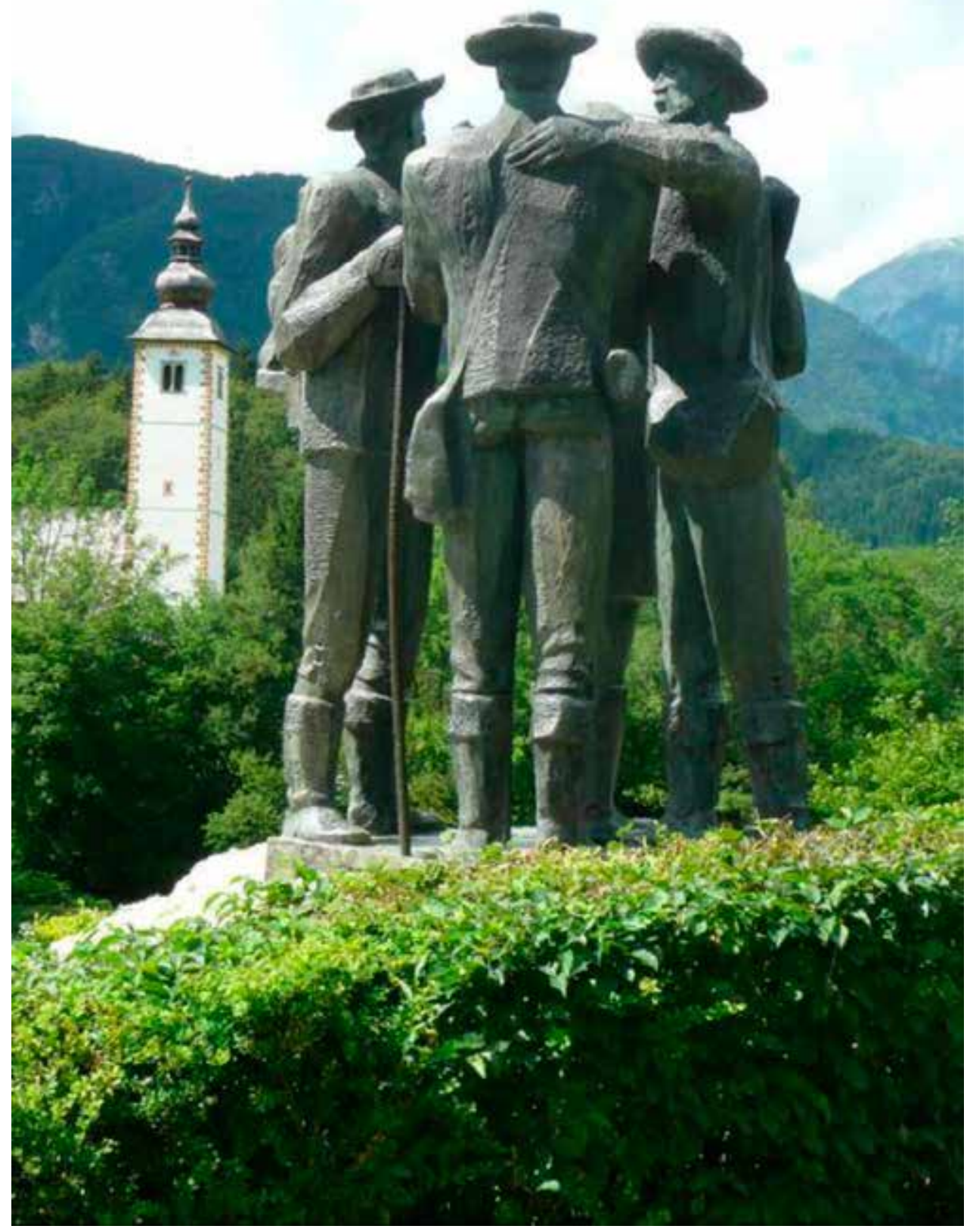

Photo of statue commemorating the four brave men and their climb of Mount Triglav in 1778 (author: Grześ Zgierz - source: https://geolocation.ws/v/P/64847190/photo-at-461640-00n135312-34e/en\#). 
Bohinj with the rest of the then Austro-Hungarian Empire in numerous directions: with the Goriška and Primorska regions — including the important port of Trieste — as well as with the Gorenjska region and beyond, including Jesenice, Klagenfurt (Celovec), even Vienna.

Until the construction of the railway, Bohinj had been accessible only by way of badly maintained roads - which was the norm for such places during that period. The cargo routes along the Bača River and through the Soteska Valley were the only connections to the outside world along which Bohinj could carry out any forms of trade. The new railway connections increased the range of Bohinj's trade connections as well as the speed and ease with which products could then travel to cities and ports to which Bohinj was then connected. In this manner, Bohinj residents were able to develop a stronger trade in wood and wood products as well as in milk and milk products to replace iron ore mining as a livelihood (Budkovič 2004).

In addition to the world becoming more accessible to Bohinj in the form of new markets for their products, the railway also implied that Bohinj became accessible to potential visitors. The roots of tourism in Bohinj go back to the second half of the 19th century; however, these early visitors did not come in large numbers. The natural beauty of Bohinj and its mountains long attracted Slovenes to visit, including many well-known Slovenes who in turn also contributed to Bohinj taking on an important role in the Slovenian symbolic landscape. People would come to Bohinj primarily for hiking tours, to the point that the history of tourism in Bohinj overlaps strongly with the development of alpinism as a sport. ${ }^{6}$ This climbing tradition has also become an important component of Bohinj's heritage. The best example of this is the statue built for the so-called štiri srčne možje or four brave men — Luka Korošec, Štefan Rožič, Matevž Kos, and Lovrenc Willomitzer — who in 1778 were the first to climb Slovenia's highest peak, Mount Triglav. The statue is located a stone's throw from Bohinj Lake, and the municipality commemorates this historical event every year on the anniversary of their ascent.

Bohinj - or more specifically, Bohinj's mountains - were in these early years considered a place of natural beauty and richness to be explored. Bohinj's first quasi-touristic organization, The Friends of Triglav Society, was founded in Bohinj in 1872 to help accommodate the growing numbers of visitors coming to Bohinj on day-long hikes or longer expeditions. The society helped encourage alpinism and visitors to Bohinj in numerous ways. Society members offered their services as guides to those who wished to explore the mountains and assumed the tasks of maintaining mountain paths and training mountain guides. They also published maps and other material for those who wished to enjoy Bohinj's natural landscape. Society members thus helped render the mountains more accessible to visitors (Strojin 1978) and also aided in channeling the flows of visitors that came to the area, thus playing a historic role in the construction of Bohinj as a tourist destination.

6 For more on the history of tourism in Bohinj see Bajuk Senčar 2005, Novak 1987, Strojin 1978. 


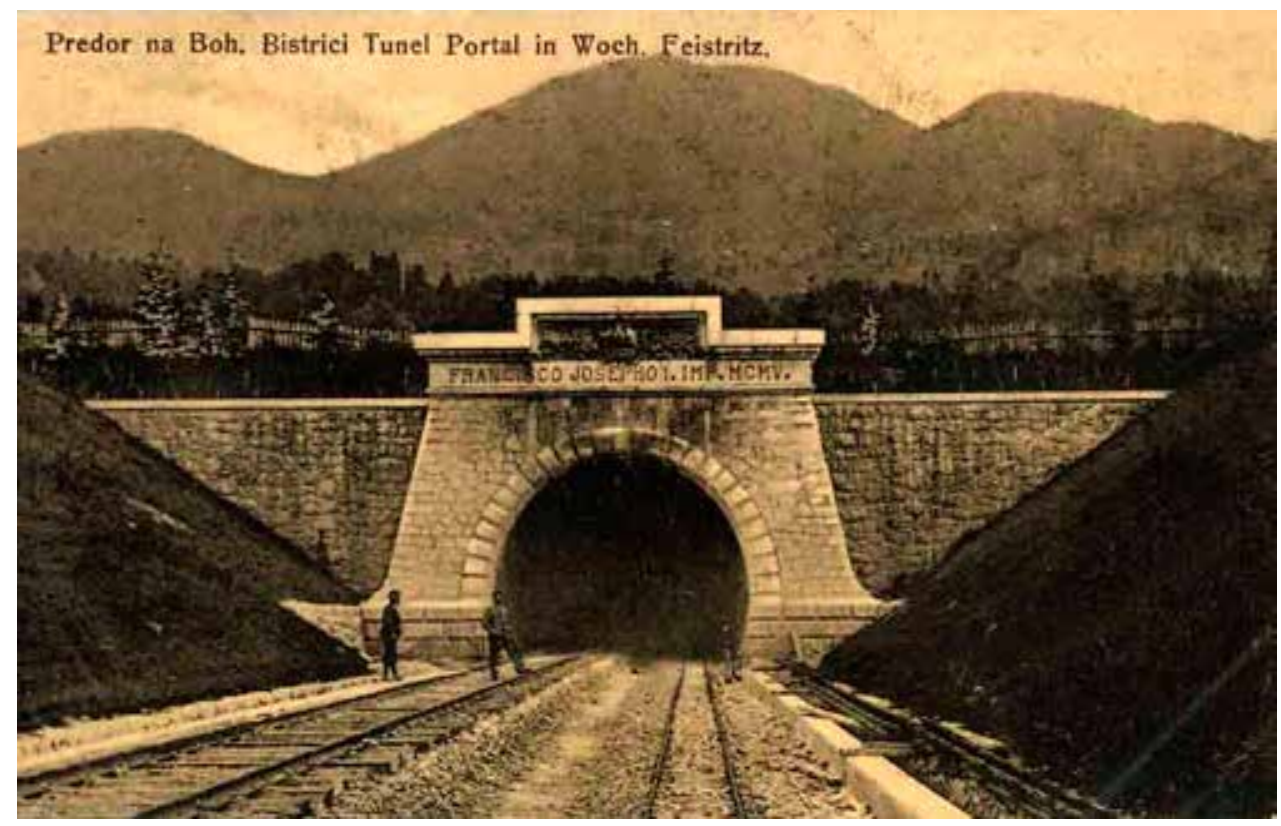

Photo of the railway tunnel in Bohinjska Bistrica , completed in 1906 (Source:Wikimedia Commons - uploaded by Gorenjski muzej).

The building of the railway in Bohinj marked a shift in the development of tourism on numerous levels, as it marks the beginning of what could be called organized or mass tourism. While until then tourism in Bohinj was something that relatively few people could indulge in, the railway connections made Bohinj accessible to much greater numbers. During the period between the inauguration of the railway and the beginning of World War I, tourists were coming to Bohinj in significantly larger numbers, which seemed to rise from year to year. The statistical evidence reflects the overwhelming changes that the railway set in motion in Bohinj as far as tourism is concerned. In 1906, for example, Bohinj registered 2350 overnight stays by foreign guests. In 1907, the year after the railway was inaugurated, this number increased to 8469 . In addition, the railway company registered approximately 10.000 day-trips to Bohinj for the year 1907 alone (Poročilo 1908).

This significant rise in tourists did not imply a corresponding rise in the number of visitors to Bohinj's Alps. Instead, the vast majority of these visitors remained primarily in and around Bohinjska Bistrica, near the railway station. This was the result of considerable efforts coordinated in large part by the Tourism Society of Bohinjska Bistrica and Srednja Vas as well as the umbrella Society for Fostering Tourism in Kranjska Province, which aided the more local organization with its projects, even financially. Both organizations were founded in expectation of the changes that the railway could bring and the potential links between transportation and tourism. Local actors involved in these projects expressed their views in the following excerpt from the first reports of the Society for Fostering Tourism in 
Kranjska Province: "The building of the Bohinj railway, which rendered accessible an entire range of places hitherto closed off to the world, was the main reason for the establishment of a special society for the encouragement of tourism...."

This shift of tourism to Bohinjska Bistrica was also the result of coordinated efforts at the local and regional level to promote tourism not only in the summer but also in the winter, which until then was considered a "dead" season. Editors of the serial publication Promet in gostilna (Travel and Tavern), founded in 1908 to support the development of tourism, arts and crafts, and the hospitality industry, also cited another reason for the development of winter sports tourism: the urban, well-off middle class' need for physical exercise. The editors argued that while the middle class has started out with fewer means, their businesses began to flourish, and they became comfortable both financially and physically. This resulted in their taking less and less time to exercise and spend time outdoors.

The only physical activities that the middle-class had at their disposal were: hunting, fishing, shooting at shooting ranges, and, in the winter, skating on some frozen pond or dancing in warm dance halls. We can say that the main sport that our middle class now indulges in is eating fried chicken and wine on Sundays. ${ }^{8}$

The solution that the editor offers for this problem was to invite members of the urban middle class to take part in physical activity and sports at locations that were accessible with public transportation and whose natural features made them ideal destinations for winter sports. Bohinj stood out among the potential destinations for so-called zimski-športni turizem, or winter-sport tourism, and discussions among tourist actors of the time centered on promoting Bohinj as a destination that could capitalize on its natural features:

As we have pointed out, the regional tourism society wishes to aid in the introduction of winter sports of all kinds, paying great attention to the development of winter tourism in Bohinj because this very place, due to its location, is meant to become for Trieste and the Primorska region what Semmergin is for Vienna and Lower Austria. /.../ The favorable snow conditions in Bohinj and the railway connections clearly accord this place an advantage among other locations in the Gorenjska region. /.../ Bohinj is a most favorable environment for winter sports in all its categories, for snow lies there every year from December to April. ${ }^{9}$

7 Poročilo o delovanju deželne zveze za tujski promet na Kranjskem: leta 1906 in 1907 in program za bodočnost - Promet in gostilna, 1, 1908, p. 2.

8 Nekaj o zimskem športu, Promet in gostilna, 1, 1908, p. 5.

9 Zimski šport. 1909. Promet in gostilna, 8, 1909, p. 75. 
Bohinjska Bistrica and its environs were built up as a center of winter-sports tourism, once again demonstrating the links between Bohinj's tourism development and that of sports. Instead of alpinism, winter sports tourism focused primarily on skating, skiing and sledding, which involved capitalizing on the natural features that could attract visitors interested in such activities. Lake Bohinj, which was otherwise lauded as a natural attraction, was reframed in the context of winter sports tourism as a first-rate, natural ice skating rink. (Batagelj 2009). The introduction of local transport from the railway station to the lakeside facilitated the visit of larger numbers of tourists.

The efforts to transform Bohinj into a destination for winter sports tourism also included the building of sports facilities within the vicinity of Bohinjska Bistrica that would attract visitors in larger numbers, including, for example, the ice skating rink Danica and the sledding course Belvedere. These two large projects were also accompanied by the construction of additional hotels in Bohinjska Bistrica, and all these novelties contributed to Bohinj becoming one of the important centers of winter sports tourism in the Gorenjska region. Furthermore, this success was also due to the special weekend prices that the railway would offer for trips to Bohinj, a pricing policy that began in 1908. On Sundays and holidays, trains would have additional "zabavni vozovi" or "leisure/excursion cars" for those going on such trips, and the discounted tickets also provided free transport of sport-related baggage — sleds, skis, etc. (Batagelj 2009).

The successful collaboration among numerous local and regional tourism actors in the production of Bohinj as a winter sports destination in effect hinged on their effectively making winter sports accessible to different groups of potential visitors. This included the publication of promotional material, facilitating access to Bohinj via public transportation, providing accommodation, restaurants, and, of course, sites for the practice of winter sports in the vicinity of the railway. This would provide the basic amenities both for visitors who would come to spend a few days in Bohinj as well as for one-day visitors. Accessibility not only entailed the creation of the routes of transportation that could transform places along these routes into destinations and facilitate the mobility of visitors to, from and among destinations. In this context, accessibility also implied offering modes of transportation that were economically feasible to a broader spectrum of people - through the introduction of public transport, pricing policies, and other amenities that would make travel to destinations as carefree as possible. The production of Bohinj as a destination for organized tourism thus was a result of the numerous elements, including the creation of a new level of accessibility.

In these last paragraphs, I have been tracing out in broad strokes the face of early, unorganized tourism in Bohinj with roots in Slovenia's history of alpinism as well as the key elements of Bohinj's transformation into a winter-sports tourism destination, which heralded the beginning of organized tourism in Bohinj. In particular, I have focused on the ways in which the existence of the railroad as a new mode of mobility was linked to the creation of Bohinj as a tourist destination for organized tourism as well as to the production 
of a particular image of Bohinj framed in terms of winter sports. Existing sources provide evidence of the efforts to instrumentalize this new mode of transport to foster the growth of tourism as an economic sector.

In the following section, I address the ways that existing forms of mobility shape the present face of tourism in Bohinj. In so doing I focus on the main distinction between the past and present-day tourism in Bohinj: the predominance of the automobile as the primary mode of transportation and tourist mobility. Furthermore, the automobile also represents the mode of transport in terms of which Bohinj's accessibility as a tourist destination is defined. While in these last paragraphs I have examined the ways in which mobility fostered tourism development, in the following section I portray the ways in which social actors view the challenges that tourism mobility represents for sustainable development in Bohinj.

\section{THE LIMITS OF SUSTAINABLE MOBILITY AND TOURISM}

Tourism development in Bohinj changed radically during the 20th century as a result of two world wars, the formation of three countries, the subsequent retracing of national borders, the implementation of a range of political systems, and countless waves of economic reforms. Furthermore, tourism as an industry - at local, national, and global levels - went through a series of wide-sweeping changes. Despite the fact that these changes triggered periods of growth, crisis and adaptation, certain features of Bohinj's remained constant. The most important of these is the central role accorded to nature in the promotion of Bohinj as a tourist destination.

One of the key events that have contributed to the role of nature in Bohinj's tourism landscape during these decades was the creation of Triglav National Park. When founded in 1924 as the Alpine Conservation Park, it encompassed a rather small region in the Julian Alps called the Triglav Lakes Valley. It was first expanded and renamed Triglav National Park in 1961 and attained its present size in 1981. The expansion of the park implied that over half of Bohinj was redefined as a protected area, and this fact has played an ever more important role in the way that Bohinj's landscape is experienced and portrayed (Bajuk Senčar 2012). This included a shift towards the heritagization of the natural landscape and a consequent change in tourism practices from Bohinjska Bistrica - which formerly operated as the center of tourism in the area - to Bohinj Lake and numerous other natural attractions.

The official website for Bohinj tourism lists numerous activities associated with particular forms of interaction with the natural environment. Suggested activities include hiking, climbing, biking, fishing, horseback riding, water sports, adventure sports, paragliding, and winter sports. These activities facilitate diverse ways of relating to the natural 
environment. ${ }^{10}$ In different contexts, nature becomes either a source of relaxation and escape, a landscape to be explored, or a source of recreation with the aid of various sports, including even some extreme sports. ${ }^{11}$ The vast majority of these activities would take place in natural environments as opposed to "man-made" ones; exceptions to this include ski resorts (for both downhill and cross-country), adrenalin parks, and horse riding facilities. It is, of course, difficult to maintain a hard and fast distinction between the natural and man-made, as paths and routes of numerous varieties facilitate or even condition access to natural attractions, including Mount Triglav.

Another distinctive feature of contemporary tourism in Bohinj is that the high season for tourism in Bohinj is in the summer, mostly in the months of July and August. The peak of the high season is the first two weeks of August, which are often also the hottest two weeks of the summer. Bohinj also has a winter season, with visitors coming mostly in the months of January and February. However, three times more visitors come to Bohinj in the summer as opposed to the winter (Lešnik Štuhec et al. 2012-A: 123).

Bohinj has to some degree become a victim of the seasonal nature of its tourism in its present form. According to one of my informants working in Bohinj's tourism industry, visitors have over the past decade or so occupied only $30-40 \%$ of Bohinj's accommodation capacities, if one calculates the yearly averages. However, the vast majority of those visits are concentrated in the summer months of July and August (with winter peaks in January-February). There have also been moments in the peaks of the summer season that all Bohinj's accommodations are full. However, those who are lodged in Bohinj represent only a percentage of Bohinj's tourists. The percentage of Bohinj's daily visitors during the high season has been increasing steadily in the past years, a situation that, according to locals, has caused a range of problems. SC, who lives in the village of Stara Fužina, outlined the reasons for this steady increase of daily, often Slovene, visitors in the last few decades:

SC: One of the reasons for our traffic problems is that we did not get this surge in the number of bathers, the daily ones, until 1991. This trend - going to natural lakes, rivers and the like - this developed with the onset of the Yugoslav war, which closed off access to the sea. This changed things alot /../ and there were also climate changes. All of a sudden we had really hot summers. Now things have changed so much in these past 25 years that we now get thousands of people who are seeking natural swimming areas for the day so they can cool down. They are from this area, including those from the upper Sava valley

10 See, for example, http://bohinj.si/en/experiencing_bohinj?fAct=searchExperiences\&pager=1\&sortD ate $=\&$ sort Availability $=\&$ sortPrice $=\#$ showHere

11 Lešnik Štuhec et al. 2012. Dokument A: Analiza turistične destinacije Bohinj / Document A: Analysis of the Bohinj Tourist Destination, p. 112. For an analysis of the ways that the practice of sports informs the protected landscapes within Triglav National Park see Poljak Istenič and Kozorog 2014. 
- meaning Jesenice, Kranj, and of course down to Ljubljana, and then those from the Ljubljana basin. All of a sudden we are dependent on what the summers are like. For example, virtually no one came last year, but this year is a problem because of all the heat waves. Clearly this sort of situation will repeat itself, and we will have to plan for it, that there will be more summers like this. ${ }^{12}$

As SC recounts, one of the events that strongly influenced tourism development and tourism practices in Bohinj as well as Slovenia in general was Slovenia's independence and the Yugoslav war that broke out soon thereafter. Until then, many Slovenes would travel to what was then the Yugoslav seaside during the summer. However, the armed conflict in many of the then former Yugoslav republics prevented access to these tourist destinations, and Slovenes turned to alternative destinations, including destinations within Slovenia. The lack of access also affected those guests from the Yugoslav republics that would otherwise come to Bohinj. Many of my informants who worked as tourism service providers claimed that they lost more guests than they gained and that it took quite a few years for Bohinj to adapt to the effects of the Yugoslav wars on its tourism.

In addition to there being a higher percentage of Slovenes among Bohinj's tourists than before, SC also describes a new group of tourists as daily visitors who - despite the range of activities offered to potential visitors to Bohinj - are focused primarily on bathing in Bohinj Lake. The increasing numbers of daily visitors in his mind are also due to the rising summer temperatures and subsequent heat waves, which makes cooling off a primary goal during vacation periods. The percentage of daily visitors is significantly large enough that their presence or absence — due to weather and temperature levels — significantly affects the tourism landscape. When the weather is "bad" (i.e., cool or rainy), Bohinj is empty; if the weather is "good", Bohinj is full, even crowded. There is also a significant difference in the number of persons during high season at Bohinj Lake during the week and during peak weekends, evidence of the significant numbers of daily or weekend visitors as an ever larger proportion of Bohinj's visitors.

As a result, Bohinj's residents deal with the high volume of traffic coming in and out of Bohinj during the hot summer months. On the weekends, traffic is virtually constant, ingoing in the morning and outgoing in the afternoon, with a brief respite in between. While there are numerous forms of public transportation available to those who wish to use it, the vast majority of Bohinj's visitors come by car, normally through Bled, the Soteska valley, and to Bohinjska Bistrica. From there they travel the road that winds along the so-called lower valley — linking Bohinj's municipal center, Bohinjska Bistrica, with the villages of Brod, Savica, Kamnje, Polje, Laški Rovt, and Ribčev Laz, which is at the eastern end of Bohinj Lake. From there it is possible to either continue on the road along

12 All interviews, save one, were conducted in Slovene, and all interlocutors are remain anonymous. 
the lake's southern shoreline to the village of Ukanc on the western end of the lake or to drive across the bridge and follow the road through the village of Stara Fužina and on through the so-called upper valley.

The effects of traffic on the daily life of locals and visitors depends on numerous factors, the most important of which is location. For example, I interviewed a local, SL, who lives in the village of Gorjuše, located at 1000 meters above sea level, in the hills above the upper valley and relatively far away from the major roads along which visitors access Bohinj and from the lakeside. When I asked him what these flows of tourists in the high season weekends meant for him, he replied in the following fashion:

SL: Basically, if we are at home and don't go anywhere, we don't feel it... There can be 20,000 persons at Bohinj Lake and we wouldn't even know about it. However, the moment that we appear in those areas, this does affect us and does make things a bit difficult for us.

Proximity thus is a significant factor, as the experiences of those persons who live in the villages that lie closest to the road demonstrate. One such village is Kamnje, located in the lower valley. The road winds through the village itself, and the path that the road takes through the village was once wide enough for carriages. Later these roads were simply widened and paved with asphalt to accommodate automobile traffic. As a result, roads were expanded to run right alongside houses, often without even enough room for a sidewalk that would allow pedestrians to walk safely through the village. Those whose homes are located alongside the road have to learn to live with the sounds and effects of constant automobile traffic, as AL, who lives in the village of Kamnje, explained to me:
AL: As I mentioned earlier, I live right by the road, and it is an unbro- ken stream of cars that drive by. This is surely a negative factor, and it is also a safety issue because crossing the street or walking along the street becomes very problematic. You become less mobile, you decide fewer times to go somewhere with your car, you choose instead to use your bicycle.

Despite living in different areas of Bohinj, both SL and AL speak in terms of a discourse common to virtually all the persons with whom I spoke when I asked about how summer traffic affected their everyday lives: diminished mobility. Diminished mobility encompassed a range of issues, from safety to accessibility to flexibility. Locals feel that the traffic associated with the high season forces them to rethink their practices of mobility in diverse ways. For some, certain modes of transport — such as walking or cycling — along the major channels of traffic became less feasible due to the volume of cars and consequent feelings of diminished safety. Others decide to rely less on their cars to get around 
and employ alternative modes of transportation as well as alternative routes (such as bike paths) to avoid traffic and problems with parking, which would render certain places less accessible, but not all, as SL explains:

SL: We have to adapt; when we go about our daily or weekend errands, I couldn't say that they are made more difficult or impossible. I can still get parking in Bistrica when I go shopping, even on Saturdays and Sundays. The problem is if I want to do the same thing as the tourists. Like going swimming in the lake. We have had these nice weekends, and I wanted to take my children to the lake. People were parked everywhere, and at one o'clock in the afternoon, despite knowing the area really well, it was impossible to find a place to park.

The high volume of traffic also implies a correspondingly large number of cars, whose drivers search to find the most convenient (for them) parking space. Such a volume of traffic creates problems of mobility that are not diffused equally across Bohinj, but primarily along certain routes, in certain directions, and at certain times of the day. This means that not all locations become inaccessible in equal measure, but mostly those that are closely linked with tourists (and their cars) that become least accessible. The high number of parked cars are concentrated around Bohinj Lake, the primary goal of daily visitors. ${ }^{13}$ Daily visitors' desires to drive to Bohinj on their terms — at the time and date of their choosing — strongly overlaps with what Böhm et al identify as the key tenets of automobility's regimes of truth: convenience and individuality (2006: 6-7). The realization of these tenets is facilitated and limited by the infrastructure of automobility (Böhm et al. 2006, Urry 2004) built into Bohinj's landscape that channels traffic - including roads and parking facilities. Results of this tension include traffic congestion at key junctures, parking lots at capacity, and a great deal of illegal parking as visitors try to reconcile their desire for convenience with the limits of legal parking in the vicinity of the lakeside. As a result, numerous social actors, including tourist organization officials, local community officials, municipal officials, traffic wardens, and park administration officials, dedicate countless hours during peak weekends to regulate traffic and parking near the lake and other key natural attractions.

The reality of traffic and parking congestion on peak weekends not only causes problems for locals such as the ones depicted above. The state of affairs during the peak season also is considered to create problems for the Bohinj's tourist industry and Bohinj's image as a tourist destination:

13 Other relevant parking sites where visitors park include those at the starting points of hiking paths into the Julian Alps above Bohinj Lake, such as the parking lots at Planina Blato. While these cases include a much smaller number of cars, they are also quite problematic because the demand for parking far outstrips the number of available legal spots and because the routes to access the parking lot are not made for high levels of traffic. 
BE: We are here at a crossroads: on the one hand, we invest a lot of funds to promote Bohinj abroad. We market peace, nature, the national park, and so on. We have a whole range of products - like the Bohinj Guest Card - to help guests enjoy Bohinj. As a result, people come to Bohinj at the peak of the tourist season, and they can't enjoy any of it because they are overrun by daily visitors.

BE, a local who works in the tourist industry, focuses on an important issue that goes beyond daily experiences of residents to address the experiences of tourists. Automobile traffic on the weekends is thus not only considered a threat to the peace and quiet of locals, who are not necessarily involved in the tourist industry. BE explains that the high numbers of daily visitors and their cars also undermine the elements of peace and nature central to Bohinj's image as a tourist destination that visitors then expect when they come to Bohinj. Local actors in the tourism industry have called attention to the fact that the steady increase of daily visitors on the weekends has begun to drive away other kinds of tourists, particularly those who come to stay in Bohinj for more than a day.

This has resulted in the general recognition of the rising number of daily visitors coming in their cars on the weekends as a growing problem in Bohinj, despite the fact that residents may have divergent interests concerning tourism and thus may interpret the issue of daily automobile traffic in different ways. One could argue that there is a consensus that the present situation concerning automobile traffic is quickly becoming unsustainable, and local and national actors have drafted a range of measures and strategies to improve the current situation.

\section{SUSTAINABLE MOBILITY AS TOURISTIC PRACTICE}

These measures fall into two groups. The first group of measures focuses on the automobile traffic/parking situation during the high season and on elaborating strategies that would diminish the number of cars arriving at the lakeside but not decrease the number of visitors. They involve, at the most basic level, the channelling of traffic and parking based on the existing system of paid parking lots and the introduction of overflow parking lots, each of which a bit further from Bohinj Lake. They also focus on directing pedestrian traffic to the lake so as to prevent visitors from walking across private, arable farmland in their desire to take the most direct route from overflow parking lots to the lakeside. However, merely trying to channel the flow of cars does not stem automobile traffic nor does it do away with the direct access to the lake and other natural attractions that also result in illegal parking. Local municipal and tourist organizations have over the years ordered mobility studies that would serve as a basis for stronger measures, including the construction of alternative 
traffic routes and the stemming of tourist traffic to the lakeside. ${ }^{14}$ These measures aimed at introducing a sustainable mobility policy during the high season would ideally decrease the pressure of automobile traffic at the lakeside and surrounding areas. Such measures would also impose order through measures that would change existing mobility infrastructure on the ground to channel and control flows of visitors more effectively, visitors whose present numbers (and automobiles) render circumstances on the ground chaotic. One of my informants described this situation as "mass tourism", in which the term "mass" refers not only to numbers but also to a level of disorganization resulting from persons having virtually unrestricted access to Bohinj's natural attractions with the aid of their cars.

The second set of measures try to resolve an issue that the first set of measures does not address: the reasons for Bohinj's high demand as a tourist attraction in the high season. Measures that fall within this second category, including the International Wildflower Festival, are longer-term strategies that address the sustainability of tourist mobility by engaging the image of Bohinj as a tourist destination, its primary elements, and the ways in which Bohinj's image is affected by the practices of tourists who come to visit. More specifically, these sorts of measures deal with the issue brought up by BE, namely the ever greater role that high numbers of daily visitors play in defining Bohinj's touristic landscape both in discourse and in practice. These large numbers are strongly linked to a particular understanding of Bohinj's lakeside as a haven during hot summer weather. As mentioned before, the number of visitors fluctuates in function of the weather on the weekends: if the weather remains dry and hot, the lakeside is swamped, if it is cool and rainy, the lakeside is virtually empty. Thus among those who comprise this particular group of Bohinj's visitors, Bohinj is attractive as a tourist destination during a limited period and under favorable weather conditions.

This image of Bohinj as an oasis or haven defined in this manner dominates the scene during the high season; however, it corresponds primarily to those visitors who, due to their large number (and their cars), are most visible during the weekends. The measures that fall into the second category are dedicated to expanding the range of elements that comprise Bohinj's image as a tourist destination and thus also potentially extend the range of tourist practices and mobilities. Some of these initiatives directly address this image of Bohinj that is prevalent during the summer by highlighting certain aspects about Bohinj that the dominant image of Bohinj does not address.

14 The author is collaborating with the TNP Public Administration and Turizem Bohinj as well as a number of other partners who together have received funding in 2015 on the part of the Norwegian Financial Mechanism to carry out a project aimed at decreasing automobile traffic near Bohinj Lake. The project is centered on the creation of an ITS system in order to provide real-time information about the status of parking lots near Bohinj Lake, the construction of a low-fare outflow parking lot in Bohinjska Bistrica and free transportation to the lakeside, and the implementation of measures to encourage alternative forms of mobility. In addition, the project also includes the drafting of a public relations strategy aimed at a range of target public audiences - including daily and longer-term tourists (both national and international), residents and tourism actors. This strategy is based on research, which is still in progress. 
I had first heard about the importance of wildflowers for Bohinj's tourism during my first round of fieldwork in Bohinj almost 15 years ago. I had been researching tourism as a local and global practice as well as a livelihood strategy in Bohinj. One of the questions that interested me was the ways in which tourist actors in Bohinj viewed tourism as a a livelihood. The vast majority of my informants would argue that making a living off tourism alone in Bohinj was not feasible and that they worked in tourism only part-time. The most common reason for this was the fact that the tourist season was simply too short. However, one of the persons that I spoke with stood out because he vehemently argued the opposite. Despite common opinion, he believed it was possible to make a living in tourism. He had been running a successful business, a pension house, for many years and believed it was possible to attract guests outside the high season. As an example, he told me of a group of guests that had been returning to his pension house every spring, year after year. Their main reason for coming to Bohinj outside the high season was they would come to see Bohinj's wildflowers in bloom.

While residents valued wildflowers for numerous reasons and are now very active in the organization and performance of the festival, the idea for a festival centered on wildflowers was not triggered at the local level. Instead, tourists - more specifically one tourist in particular - played a significant role in developing the initiative for the festival. Longtime visitor to Bohinj and conservationist Ian Mitchell argued the necessity of promoting Bohinj's wildflowers and Bohinj as an ideal landscape for subalpine flowers, which in Europe have become a rarity:

Ian Mitchell: My main reason for coming to Slovenia for so many years is that Bohinj is a beautiful place. You have here an environment, and especially in terms of subalpine wildflowers, one of the best locations in Europe, possibly the world. The Bohinj festival and the Julian Alps have actually been identified last year in a new publication about the best wildflower places in the world, and it's in the top fifty. I don't think that many people, especially in Slovenia, just realize how important this area is. Many people just think, it's just Bohinj, it's just wildflower meadows. It's normal. But a huge proportion of the European population are urban - about $80 \%$ of the population live in cities - and to those of us who come from completely different climactic areas, this is just amazing. Even on a rainy day in Bohinj you have amazing landscapes. ${ }^{15}$

In this passage, Mitchell touches upon a number of issues that provide the framework for the heritagization of Bohinj's wildflowers. Speaking from the perspective of a

15 Mr. Mitchell's singular role in the organization of the festival and his status as a public figure rendered it impossible for him to remain anonymous. He has graciously consented to the publication of excerpts of his interview. 
conservationist and longtime visitor, Mitchell highlights the value of wildflower meadows at the level of Europe understood as a continent whose industrial and agricultural practices have rendered wildflower meadows anything but normal. He argues that while wildflowers are an everyday component of the natural landscape for Bohinj residents, they are also an important element of natural heritage — both at the national and European levels. Furthermore, he argues that the amazing wildflower landscapes with rich biodiversity are the reason numerous British tourists return to Bohinj, regardless of the weather:

IM: I sat down once with a lady who was president of the Botanical Society of the British Isles; she is a very well known lady in Britain, Mary Briggs. She is now in her 90s. We were all saying how lovely Bohinj was, and Mary Briggs used to lead professional holidays for botanists from the UK. And they always went to Hotel Zlatorog in Ukanc. She told me absolutely without any doubt that Bohinj was the best place for subalpine flowers in Europe. No question about it. She had been all around the world and for high alpines, maybe Switzerland takes the gold medal. For subalpine, what you get in the alpine meadows, Bohinj was one of the best in the world and the best in Europe.

The idea of organizing a festival dedicated to Bohinj's wildflowers emerged from the initial collaboration between Ian Mitchell and members of Bohinj's local tourism office. Upon receiving the support of both the Bohinj municipality and Triglav National Park administration officials, the International Wildflower Festival was established in 2007. The two-week festival is held in late spring (late May - early June) and is dedicated to celebrating and raising awareness of the value of Bohinj's wildflowers and their role as an important element of local heritage. The festival's organizers cite links between the relatively new festival and the early days of Bohinj's tourism, when people would make their way to Bohinj to admire its distinctive flora and fauna:

Even before /.../ the railway enabled the development of tourism in Bohinj, people had visited Bohinj by carriages or on (foot) so they could see and admire the picturesque and interesting flora and the beauty of nature. Balthazar Hacquet (1739 or 1740 - 1815), renown(ed) Breton natural scientist, traveler and explorer, wrote passionately on botanical riches of Bohinj mountains./.../ Many other explorers and admirers of Bohinj's botanical riches followed him. From early spring, when first flowers sneak out from under the snow, until autumn, Bohinj offers the experience of magnificent beauties of alpine flowers. ${ }^{16}$

16 Excerpt from http://www.bohinj.si/alpskocvetje/eng/o_festivalu_predstavitev.php. 


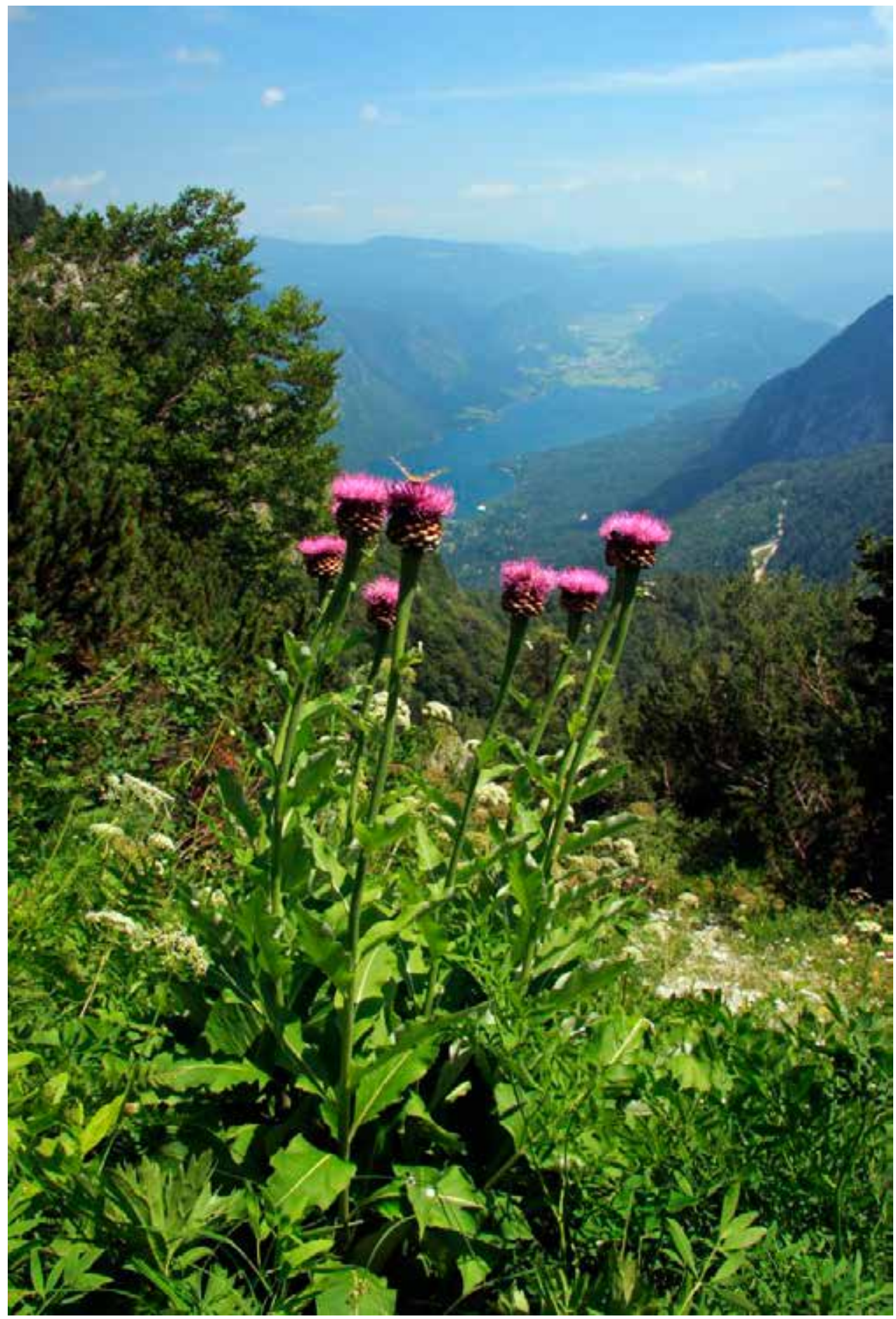

Promotional photograph of alpine wildflower framed against the backdrop of Bohinj Lake (Rapontika - Stemmacantha rhapontica). Photo: Peter Strgar. 
The festival is depicting as continuing the tradition of visitors traveling to Bohinj to admire its botanical riches by organizing so-called botanical tours. The festival centers on guided botanical tours either of Bohinj's botanical gardens or of chosen routes in order to admire the distinctive flowers to be found in a range of Bohinj's natural landscapes. The map below traces sixteen botanical guided tours, along which visitors can admire the species of flowers that grow in different habitats. The tours range in difficulty, rendering them accessible to diverse groups. The guides that lead these tours are normally botanists, though other experts also take on this role, depending on the emphasis of these tours. ${ }^{17}$

The festival thus hinges on the creation of botanical routes and the implementation of a particular form of tourist practice along chosen routes. The performance of these tours along these routes helps create floral landscapes. In this manner, festival organizers and actors write alpine wildflowers into narratives of Bohinj's natural attractions and elements of natural heritage:

Not many regions in the Alps can boast a more diverse flora than the area of Bohinj! This relatively small area is characterised by several altitudinal belts up to the highest peaks reaching far above the forest line. Vast forests, fields, mountain meadows, and various wetlands - from the shore of Lake Bohinj to the high moors. All this gives an attentive nature lover a chance to experience unforgettable beauties and discoveries. ${ }^{18}$

While the official discourse from the festival's website cited above portrays Bohinj as a landscape of rich floral biodiversity, the organizers' approach was not only to add wildflowers to Bohinj's map of natural attractions but to present them as an integral element of Bohinj's cultural heritage. Festival events are also dedicated to portraying how wildflowers are embedded in everyday life in Bohinj. One important strategy involves portraying how residents are and have been involved in the creation of floral landscapes as cultural landscapes. This is an important issue covered in the festival's promotional discourse, as it apparent from the following excerpt:

Numerous plants owe their existence and survival to people. The thousand-year lasting cohabitation of human and nature has formed the landscape in the Julian Alps and also a living space for many plants. Without the diligent work of the local people the fields would be overgrown by forest, which would higher in the mountains turn into

17 Other sorts of tours were added on to the schedule as the festival developed, including apicultural tours and ornithological tours. In addition, some of the botanical tours had a more specific purpose in mind: for example, one of the tours that I participated in was focused primarily on those flowers that could be used in cuisine.

18 http://www.bohinj.si/alpskocvetje/eng/o_bohinju_cvetlicno_bogastvo.php 


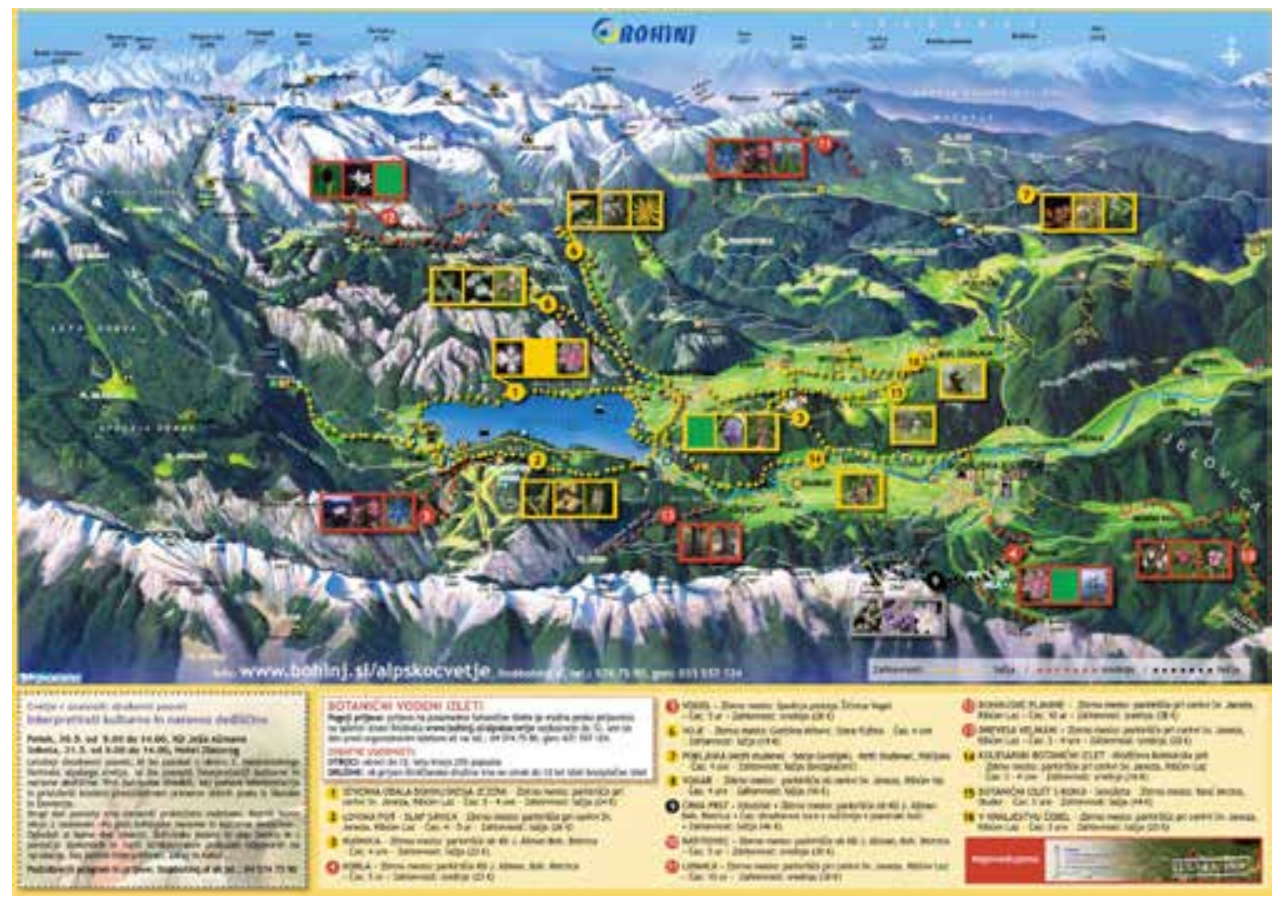

Map of the International Wildflower Festival botanical tours (source: International Wildflower Festival website, promotional material: http://www.bohinj.si/alpskocvetje/docs/program_in_ cene_2008.pdf).

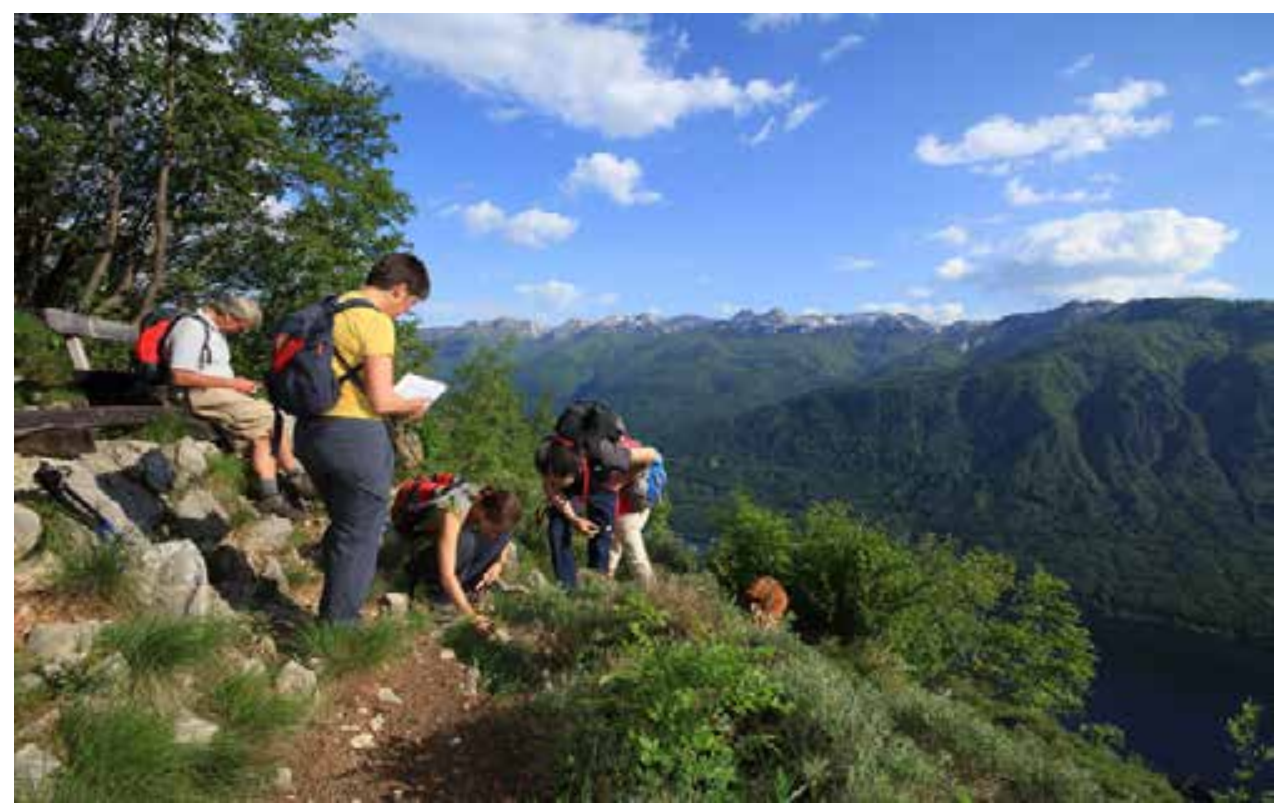

Guided botanical tour: Vogar. Author: Mitja Sodja, Foto Bohinj. 
mountain pines and rocks - all the beautiful floral richness of meadows from the valley up to the mountains would be lost. Based on the native breed of cattle - the so-called "cika", the cattle breeding required a respectful and well-considered use of what nature provides. Due to a wet climate, elaborate constructions had to be built - hayracks to dry hay and wooden hay barns to preserve the hay through the winter. The herdsmen on the high-pastures were dwelling in herdsmen huts in the mountains. All this gave the landscape around Bohinj a special character - a precious cultural landscape of immense beauty was formed, which the local people are justly proud of. For the preservation of the rich flora of Bohinj and the Alps in general, it is crucial to preserve the cultural landscape with extensive cattle breeding - with traditional ways of harvesting hay.

This excerpt depicts the creation of cultural landscapes resulting from residents' livelihood strategies - specifically, cattle breeding — and the practices linked to these strategies, including traditional methods of harvesting hay. In carrying out these time-honored methods, local actors are presented as having helped maintain low- and high-altitude meadows as one of the main habitats of alpine wildflowers and thus preventing them from being lost to the expansion of forests. Against the backdrop of the narrative frame of the cohabitation of humans and nature, Bohinj's residents are in this manner written into floral landscapes.

Furthermore, the festival also presents the multi-faceted cultural role of alpine wildflowers, thus addressing the relationship between nature and culture from a complementary perspective: namely, the way that wildflowers inform culture in its diverse manifestations. To this end, the remaining events of the festival were grouped into the following three sections: flowers in art, flowers in everyday life, and flowers in science. The first category includes all the cultural or artistic events with wildflowers as a central theme — including concerts, art and photography exhibitions, art workshops, and the revival of traditional artistic forms. The second focuses primarily on the role of flowers in everyday life, be it in the kitchen, as emblems in handicrafts, or as a source of local knowledge. Seminars, workshops, and conferences concerning sustainable development fit into the final category of flowers in science. In this last section, wildflowers serve as a catalyst for thinking through the challenges of sustainability within a protected area.

One of the festival organizers explained that the structure was to reflect the extent to which wildflowers are embedded in daily life, arguing that there is almost nothing in Bohinj that could not be somehow be linked to wildflowers. Taken together, the festival events highlight the mutually constitutive relationship between local communities and the natural environment in which they live. Furthermore, the festival as a tourist event is designed to serve as a platform for reflecting upon the direction this relationship will take, and the potential role that tourism can play in this relationship: 


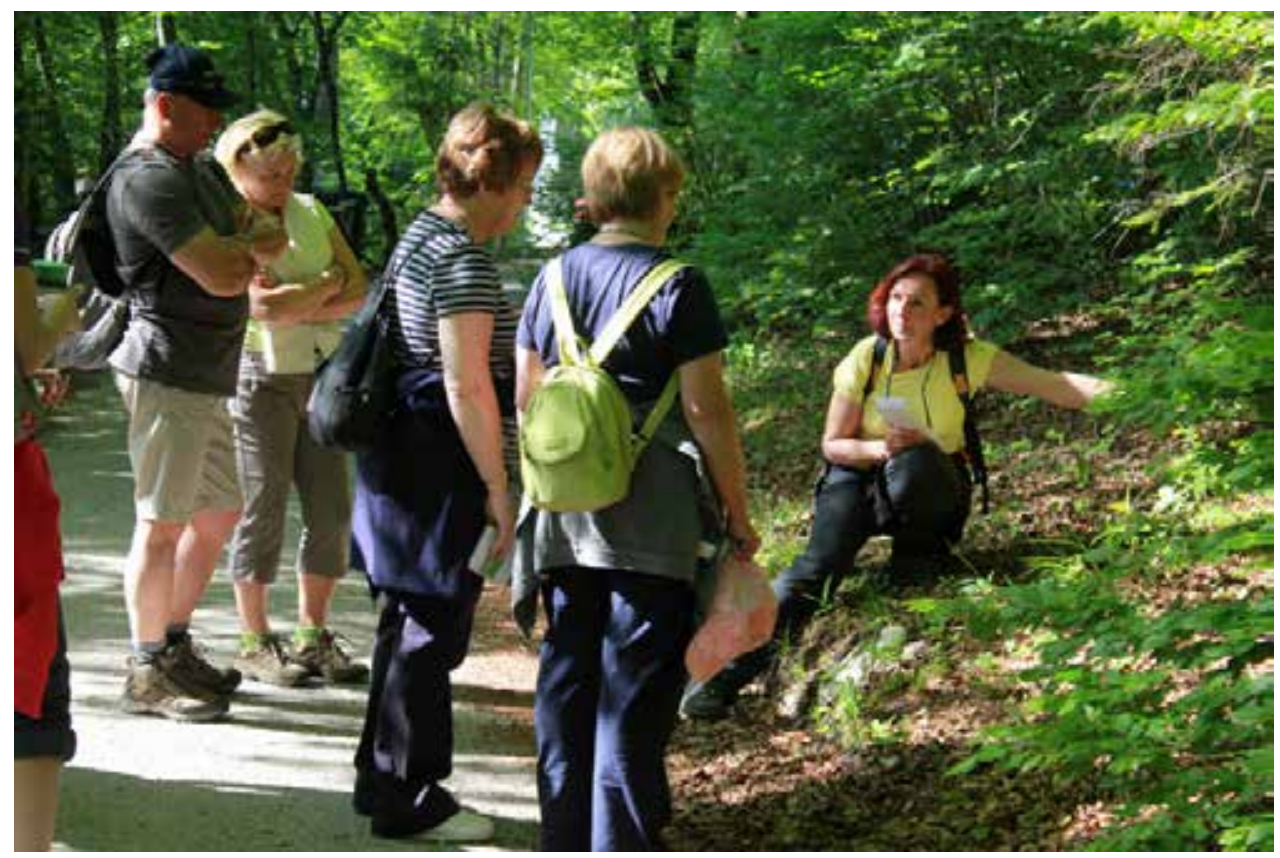

Guided botanical tour of the northern shore of Lake Bohinj (2012). Author: Mitja Sodja, Foto Bohinj.

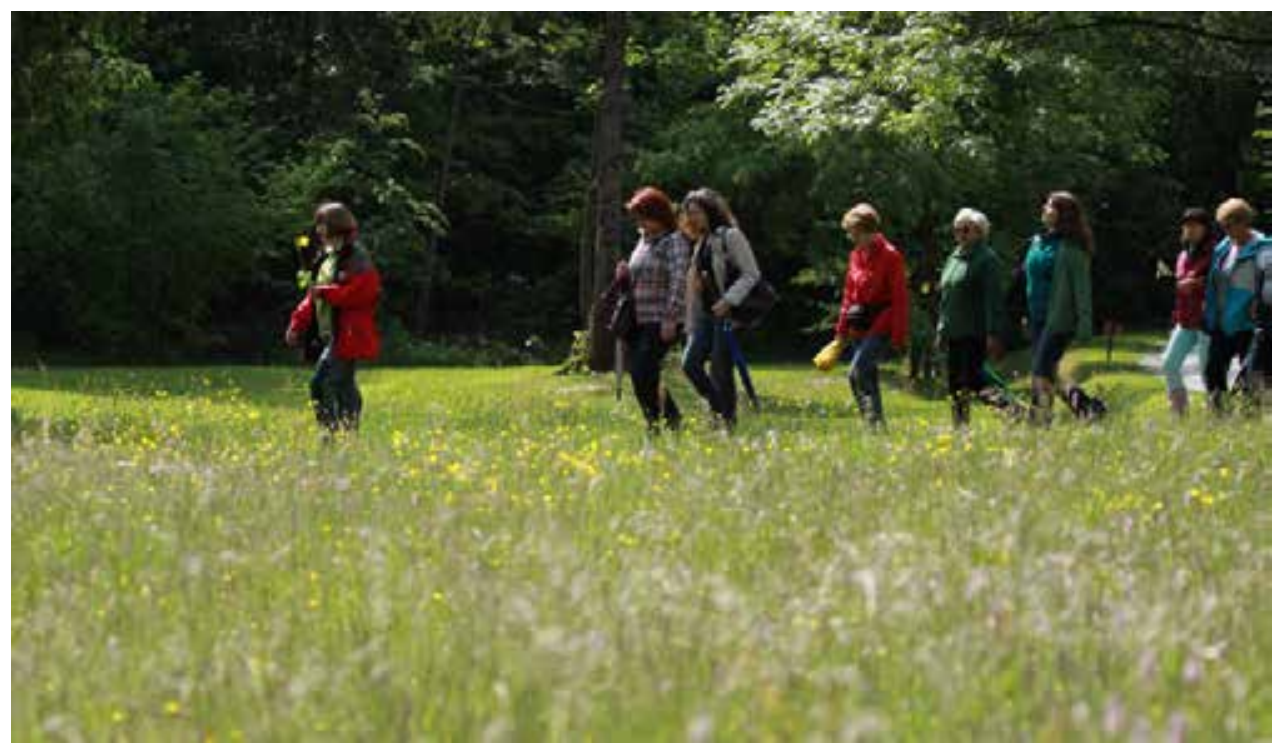

Guided tour and workshop: Flowers in the Kitchen: identifying and gathering flowers (2012). Author: Mitja Sodja, Foto Bohinj. 
LM: The only people who can know what our relationship with flowers is like are those who has lived here, who have worked in the meadows in the summer, they can explain what they mean to them. Their parents or maybe grandparents taught them to develop a certain relationship with the environment, though things may have changed now because we live in a different era. However, tourism can help in this regard, can help preserve the old ways, so that certain things that would otherwise be lost due to the world's modernity remain in this place, and that people will come here to visit - not in order to look into a display window to observe how people once lived but instead to see how people live here today.

In this passage, LM, a high-level festival organizer, advocates the intrinsic value of locally rooted heritage linked to alpine wildflowers and a traditional relationship to the environment as the foundation for elaborating a livelihood strategy based on tourism. For festival organizers and local participants, raising awareness about wildflowers as an important element of Bohinj's natural heritage is part of a more extensive project linked to a specific formulation of sustainable development of Bohinj. This formulation centers on linking natural and cultural heritage, alpine farming, and tourism. More specifically, it involves the maintenance and promotion of particular relationships to heritage on the part of residents that hinge on balancing heritage protection with strategies of heritage management that offer residents a viable future. The definition of the festival in these terms is apparent from the range of intended objectives, as defined in the festival's promotional literature:

- promotion and recognition of the importance of the natural and cultural heritage of Bohinj and the wider area;

- presentation of the importance of correct management of the area according to the principles of sustainable development, manifested in the simultaneous protection of the rich biological diversity of the natural environment and an improvement of the cultural and economic situation of the population;

- a practical illustration of how ecotourism and alpine farming can be key elements of the long-term economic prospects of the area and at the same time a model of development opportunities for other mountain areas in Slovenia;

— development of out-of-season tourism. ${ }^{19}$

19 http://www.bohinj.si/alpskocvetje/eng/o_festivalu_organizacija.php 
As is apparent from the excerpt above, the festival also operates as a project meant to address numerous overlapping issues that fall under the rubric of sustainability, with one of the elements being the development of out-of-season or alternative forms of tourism defined by the growth cycle of wildflowers. The timing of the festival is not defined by the schedule of Bohinj's tourist seasons. The fact that these two rhythms of seasonality do not overlap automatically renders the festival an out-of-season event. However, the category out-of-season refers not only to the timing of the event but also to the seasonality of tourist practices. Numerous tourist actors in Bohinj as well as visitors made observations to this effect, pointing out connections between the timing of tourists' visits and their distinctive forms of tourist practice:

GM: Who are your guests? Well, you get very mixed audiences who come at different times of the year for different reasons. You have the day visitor, the August and July visitor, who is completely different from the May-June and September visitor. And then the winter season is also different. After about 20 odd years of coming here, I met regularly with other guests who were coming here, to see the wildflowers and photograph the walk. You could almost guarantee that you would see the same people at the same time of year, it would be the same kind of guests.

Thus, the idea of developing out-of-season tourism can be understood in at least two ways: one the one hand, it can refer to expanding the tourist season by organizing festivals that operate as tourist events in an effort to encourage tourism mobility outside Bohinj's high season. On the other hand, the festival's events, particularly the botanical tours, also foster specific forms of tourist mobility in Bohinj, practices that are in line with a culturally grounded approach to the sustainable management and promotion of local heritage. Tourist mobilities are understood in this case to refer to the different ways that tourists travel and the range of paths that their diverse activities map out on the landscape, actvities that in turn correspond to the rhythm of tourist seasons. Promoting out-of-season tourist development can be equated with fostering "out of season" as opposed to "high season" forms of tourist mobility as well as with attracting visitors who ascribe to the "out-of-season" profile in terms of mindset and tourist activities.

\section{CONCLUDING THOUGHTS}

In the course of this ethnographic discussion, I have sketched out the history of tourism in Bohinj, focusing on specific episodes. In so doing, I have been analyzing the mutually constitutive relationship between tourist mobilities and the productions of tourist landscapes - focusing in particular on constructions and heritagizations of nature. This 
involves examining the activities of diverse tourist actors, the infrastructure as well as existing forms of mobility, which to paraphrase Urry (2004) and other mobility specialists (Böhm et al 2006 Featherstone 2004), together operate in a systemic manner. In my presentation of the history of tourism, I have examined the links between various elements of this system, including different modes of transport, tourism, and heritagizations of nature. I have portrayed the ways that changes in one dimension of this system informed developments in another. More importantly, I have also identified a range of social actors involved in the operation, maintenance and change of this system - from residents, transportation officials, tourism actors and tourists themselves. I also employed this approach to identify the key elements that inform the present challenges facing Bohinj as a tourist destination as residents, tourist actors and tourists negotiate the limits of mobility and sustainability during Bohinj's high season. This has implied involved studying the links between actors' mobile practices and touristic experiences, focusing on the effects of an ever-increasing volume of automobile traffic on the experience, practice, and promotion of tourism as well as the experience and management of Bohinj's heritage. Moreover, this study also implied addressing the different depictions of Bohinj's tourist landscape on the part of these diverse actors. One of the most significant of developments in this vein is the emergence of a local consensus about the practical appropriation of the image of Bohinj as an oasis on the part of daily visitors, whose mobilities due to their high numbers play a visible role in Bohinj's tourist landscape.

Upon discussing the different strategies that residents employ to address the issue of sustainable tourism and mobility, I analyze Bohinj's International Wildflower Festival as a touristic event and as a sustainable mobility project that hinges on the heritagization of Bohinj's alpine wildflower landscapes. Employing interviews with festival organizers and the official discursive presentation of the festival on its official website, I have examined the heritagization of Bohinj's wildflowers and the varied heritage relationships that underpin it. At the most general level, one can identify the status of heritage accorded to wildflowers as framed by the terms of nature conservation, which are based on the emphasis of the extraordinarily rich biodiversity of Bohinj's wildflower landscapes against the backdrop of an ever-more urbanized Europe. Bohinj's wildflower landscapes and their diversity are also linked to the particular geographical relief of this particular region of the Alps and its distinctive diversity of habitats. The diverse flora that results is presented by festival organizers as one of Bohinj's distinctive features and an important element of its natural heritage, for which the festival creates a specific form of tourist activity/mobility. Furthermore, the organizational structure of the festival is designed to map out the relationship between residents and wildflowers that results in the creation of wildflower landscapes and the presentation of the multi-faceted role of wildflowers in everyday life. Finally, the deliberation of wildflowers' distinctive place in Bohinj and their role in social life is not only an important dimension of heritagization understood as a social process but also the foundation for broader discussions on sustainable tourism and the role of heritage within it. 
In this manner, the heritagization of wildflowers remains an ongoing process of reflection and performance. Assessing the effectiveness of the festival as a tourist event, a performance of heritage, and a sustainable mobility project, however, implies not only examining its structure and presentation in the forms of image and discourse. It will require taking into account the roles of the diverse actors shape Bohinj's tourist and heritage landscapes - from residents, municipal leaders, park administration officials, experts, tourist actors, and tourists. They all will play a key role in defining the way the International Wildflower Festival will continue to develop.

\section{REFERENCES}

Anon. 1908. Poročilo o delovanju deželne zveze za tujski promet na Kranjskem: leta 1906 in 1907 in program za bodočnost. Promet in gostilna 1:2-3.

Anon. 1908. Nekaj o zimskem športu. Promet in gostilna 1: 5-6.

Anon. 1909. Zimski šport. Promet in gostilna 8: 74-76.

Bajuk Senčar, Tatiana. 2005. Kultura turizma: Antropološkipogledi na razvoj Bobinja. Ljubljana:Založba ZRC.

Bajuk Senčar, Tatiana. 2012. Natural and Cultural Heritage Practices in Triglav National Park. Traditiones $41(2): 53-64$.

Batagelj, Borut. 2009. Bohinj — "Slovenska Švica”: Začetki turizma v Bohinju pred prvo svetovno vojno. Kronika 57: 151-160.

Bendix, Regina. 2009. Inheritances: Possession, Ownership and Responsibility. Traditiones 38 (29): 181-199.

Böhm, Steffen, Campbell Jones, Chris Land, and Matthew Paterson (eds.). 2006. Against Automobility. Malden and Oxford: Blackwell.

Boissevain, John (ed.). 1992. Revitalizing European Rituals. London: Routledge.

Boissevain, John. 1996a. Introduction. In: John Boissevain (ed.), Coping with Tourists: European Reactions to Mass Tourism. Oxford: Berghahn Books, 1-19.

Boissevain, John. 1996b. Ritual, Tourism and Cultural Commodification in Malta. In: Tom Selwyn (ed.), The Tourist Image: Myths and Myth Making in Tourism. Chichester: John Wiley and Sons Ltd., $105-120$.

Bruner, Edward. 2005. Culture on Tour: Ethnographies of Travel. Chicago and London: University of Chicago Press

Budkovič, Tomaž. 2004. Vzpon Bohinja pred zatonom Avstro-Ogrske. Celovec-Ljubljana-Dunaj: Mohorjeva založba.

Clifford, James. 1997. Routes: Travel and Translation in the Late Twentieth Century. Harvard University Press: Cambridge, Massachusetts.

Cohen, Erik. 1988. Authenticity and Commodification in Tourism. Annals of Tourism Research, 15 (3): $371-386$.

Crain, Mary. 1992. Pilgrims, 'Yuppies,' and Media Men: The Transformation of an Andalusian Pilgrimage. In: J. Boissevain (ed.), Revitalizing European Ritual. London: Routledge, 95-112. 
Dant, Tim. 2004. The Driver-Car. Theory, Culture \& Society 21 (4/5): 61-79.

Durkheim, Emile. 1964 (1893).The Division of Labour in Society. New York: Free Press.

Edensor, Tim. 2004. Automobility and National Identity: Representation, Geography and Driving Practice. Theory, Culture \& Society 21 (4/5): 101-120.

Featherstone, Mike. 2004. Automobilities: An Introduction. Theory, Culture \& Society 21 (4/5): 1-24.

Geertz, Clifford. 1973. The Interpretation of Cultures: Selected Essays. New York: Basic Books.

Getz, Donald. 1991. Festivals, Special Events and Tourism. New York: Van Nostrand Reinhold.

Getz, Donald. 2004. Geographic Perspectives on Event Tourism. In: Alan A. Lew, C. Michael Hall and Allan M. Williams (eds.), A Companion to Tourism. Oxford: Blackwell Publishing, 410—422.

Greenwood, Davydd J. 1989 (1977). Culture by the Pound: An Anthropological Perspective on Tourism as Cultural Commoditization. In: Valene Smith (ed.), Hosts and Guests: The Anthropology of Tourism. Philadelphia: Univ. Penn. Press, 171-185.

Habinc, Mateja. 2013. Tradicionalnost prireditev Kravji bal, Vasovanje in Kmečka ohcet v Bohinju s perspektive njihovih organizatorjev. Traditiones 42(2): 85-104.

Hall, C. Michael. 1992. Hallmark Tourist Events: Impacts, Management, and Planning. London: Belhaven Press.

Hall, C. Michael. 2005. Tourism: Rethinking the Social Science of Mobility. Essex: Pearson Education.

Ingold, Tim. 2004. Lines. New York: Routledge.

Kirshenblatt-Gimblett, Barbara. 2004. Intangible Heritage as Metacultural Production. Museum International $56(1-2): 52-65$.

Kozorog, Miha. 2009. Antropologija turistične destinacije v nastajanju: Prostor, festivali in lokalna identiteta na Tolminskem. Ljubljana: Znanstvena založba Filozofske fakultete Univerze v Ljubljani.

Kozorog, Miha. 2011. Festival Tourism and Production of Locality in a Small Slovenian town. Journal of Tourism and Cultural Change 9 (4): 298-319. DOI:10.1080/14766825.2011.617453

Lash, Scott and John Urry. 1994. Economies of Signs and Space. London: Sage.

Lett, James. 1989. Epilogue. In: Valene Smith (ed.), Hosts and Guests: The Anthropology of Tourism. Philadelphia: University of Pennsylvania Press, 275-279.

MacCannell, D. 1976. The Tourist: A New Theory of the Leisure Class. New York: Schoken Books.

Manning, F. E. 1983. Cosmos and Chaos: Celebration in the Modern World. In: F. E. Manning (ed.), The Celebration of Society: Perspectives on Contemporary Cultural Performance. Bowling Green, Philadelphia: Green University Popular Press, 3-30.

Mencinger, Alfonz. 1908. Statistika tujskega prometa na Kranjskem. Promet in gostilna 1 (7): 68.

Merriman, Peter. 2004. Driving Places: Marc Augé, Non-Places and the Geographies of England's M1 Motorway. Theory, Culture \& Society 21 (4/5): 145-67.

Miller, Daniel. 2001. Car Cultures. Oxford: Berg.

Novak, Anka. 1987. Začetki turizma v Bohinju. In: Bohinjski zbornik.Radovljica: Skupščina občine Radovljica, 178-183.

Poljak Istenič, Saša and Miha Kozorog. 2014. Constructing a Protected Area as an Adventurescape: The Case of Slovenia’s Triglav National Park. Ethnologica Fennica 41.

Prentice, Richard and Vivien Andersen. 2003. Festival as Creative Destination. Annals of Tourism Research 30 (1): 7-30. 
Selwyn, Tom. 1996. Introduction. In: Tom Selwyn (ed.), The Tourist Image: Myths and Myth making in Tourism. Chichester: John Wiley and Sons Ltd., 1-33.

Sheller, Mimi, and John Urry. 2004. Tourism Mobilities: Places to Play, Places in Play. London and New York: Routledge.

Lešnik Štuhec, Tanja et. al. 2012. Strategija razvoja in trženja destinacije Bohinj 2012-2016 z vključenim modelom razvoja in trženja destinacije v obravnavanem obdobju. Bohinj.

Strojin, Tone. 1978. Gorsko društvo Triglavskiprijatelji, predhodnik Slovenskega planinskega društva. Radovljica.

Taylor, John P. 2001. Authenticity and Sincerity in Tourism. Annals of Tourism Research 28 (1): 7-26.

Turner, Victor. 1969. The Ritual Process: Structure and Anti-Structure. Chicago: Aldine.

Turner, Victor. 1982. Celebration: Studies in Festivity and Ritual. Washington, DC: Smithsonian Institution Press.

Urry, John. 2007. Mobilities. Cambridge: Polity.

Weber, Irena. 2003.Ženski itinerariji: Med antropologijo potovanja in literaturo. Knjižnica Annales: Koper.

\section{MEDNARODNI FESTIVAL ALPSKEGA CVETJA IN UVEDBA VZDRŽNE MOBILNOSTI KOT TURISTIČNE PRAKSE}

Avtorica obravnava večplastno razmerje med dediščino in turizmom v Bohinju ter analizira, kako dediščina deluje kot stičišč za obravnavo izzivov razvoja vzdržne oblike turizma v Triglavskem narodnem parku. Etnografska obravnava razmerja med dedišcino in turizmom je postavljena $v$ okviru vprašanja o turistični mobilnosti in je del raziskave povezav med turistično mobilnostjo, turističnimi praksami in podobami Bohinja kot turističnaga kraja. Mobilnost v tem kontekstu ni abstrakten pojem; je ena izmed osnovnih značilnosti turizma, ki kot kulturna praksa in kot pridobitna dejavnost temelji na gibanju oz. kroženju ljudi. Mobilnost se v tem primeru nanaša predvsem na potovanja kot prizemljeno prakso: zajema premike družbenih akterjev, poti, ki jih uporabljajo na svojih potovanjih, prevozna sredstva, ki jih izberejo za svoja potovanja, ter tudi sledove (fizične in družbene), ki jih akterji pǔ̌čajo v turistični krajini (Ingold 2004). Analitična rdeča nit je vzajemno, konstitutivno razmerje med turistično mobilnostjo in produkcijo turističnih krajin, s katerim želi avtorica orisati družbeni kontekst, ki je prispeval k nedavni ustanovitvi Mednarodnega festivala alpskega cvetja v Bohinju. Omenjeni vsakoletni festival, ki pozno spomladi poteka dva tedna, obsega vrsto različnih dogodkov, ki promovirjo in informirajo javnost o alpskem cvetju kot elementu naravne in kulturne dediščine Bohinja ter njegov pomen $v$ vsakdanjem življenju.

Omenjeni analitični pristop sloni na predpostavki, da dediščnjenje Bohinja zajema niz razvijajočih se družbenih praks, ki skupaj ponazarjajo bistvo dediščine, tj., po Barbari Kirshenblatt-Gimblett (2004), nenehni metakulturni proces. Poleg tega se raziskava osredinja na razumevanje vzajemne povezanosti turistične mobilnosti in odnosa domačinov do različnih vidikov krajine, $v$ kateri živijo, zlasti do tistih elementov, ki jim je bil dodeljen status dediščine (Bendix 2009). Na podlagi tega avtorica preuči festivala alpskega cvetja $v$ Bohinju kot turistični dogodek, ki 
posreduje podobo Bohinja kot turistično krajino, in projekt za uvedbo vzdržne mobilnosti v Bohinju. Obravnava proces dediščinjenja bohinjskega alpskega cvetja ter različne dedǐ̌činske odnose, na katerih ta proces temelji, pri tem pa analizira pogovore z organizatorji festivala in drugimi akterji ter preuči uradno, tj. diskurzivno, predstavitev festivala.

Na najsplošnejšii ravni avtorica obravnava status dedišcine, ki je dodeljen alpskemu cvetju. Uokvirja ga diskurz ohranjanja narave, ki temelji na poudarjenem bogastvu biotske raznovrstnosti alpskega cvetja $v$ bohinjskih krajinah $v$ luci vse bolj urbanizirane Evrope. Raznovrstvnost teh krajin je povezana tudi sposebnim geografskim reliefom tega alpskega območja in njegovo značilno raznovrstnostjo habitatov. Organizatorji predstavljajo cvetlično bogastvo tega območja kot eno izmed posebnosti Bohinja in pomemben element lokalne naravne dedišrine. Za njeno spoznavanje so si zamislili zemljevid botaničnih poti, ki jih ponujajo kot specifično oblika mobilnosti. Namen festivala je tudi pokazati na povezanost tega naravnega bogastva in prebivalcev oziroma poudariti značilno vlogo alpskega cvetja v bohinjskem družbenem življenju. Na ta način dedisčinjenje bohinjskega alpskega cvetja ostaja stalen proces premisleka in uprizarjanja (številne dejavnosti, ki jih organizatorji pripravijo za različne skupine obiskovalcev). Vendar mora analiza družbene učinkovitosti festivala upoštevati tudi vlogo turistov, ki sooblikujejo Bohinj kot turistično krajino. Kot akterji v sistemu (avto)mobilnosti Bohinja bodo pomembno sodoločali smeri, kako se bo Mednarodni festival alpskega cvetja razvijal v prihodnje.

Dr. Tatiana Bajuk Senčar, ZRC SAZU, Inštitut za slovensko narodopisje Novi trg 2, SI-1000 Ljubljana 